\title{
An analysis on dynamics that lead to counterfeit purchasing behavior of ICT products among youths
}

\author{
Stephen Githii ${ }^{1}$, Stephen Maina ${ }^{2}$, John N. Kamau ${ }^{3}$ \& Mary M. Njau ${ }^{4}$ \\ ${ }^{2}$ Nett Consultants, Nairobi \\ ${ }^{1,34}$ Africa Nazarene University Business School
}

\begin{abstract}
Trade in counterfeit products has become one of the world leading illegal activities accounting for billions of dollars exchanged annually. It is estimated that the trade is worth over USD 600 billion far much higher than the GDP of many developing countries. This study sought to identify factors behind this menace that is costly to individuals, companies and governments. Methodology of the study involved a cross-sectional design where a sample of 142 respondents was picked randomly to fill a questionnaire. The respondents were from middle-income families and the upper class in Kenya. This study identified perception of youthfulness, weak regulations, weak branding, external influence, irresponsibility and moral decline as some of the major factors driving counterfeit trade. Ignorance and poverty were also identified as factors contributing to this phenomenon. The study recommends more awareness campaigns even among the educated to be increased as well as development of more severe penalties on those who trade with counterfeit to deter its growth. More studies should be carried out to establish the extent to which decline in moral standards globally has contributed to this phenomenon.
\end{abstract}

Key words: Counterfeit, purchasing behavior, ICT products and youth

\section{Introduction and background}

There has been an increase in the trade of counterfeit goods world over and this has become a global phenomenon (Hamelin, Nwankwo \& Hadouchi, 2013). The three, noted that the trade amounted to USD 600 billion in the year 2012, which represent a growth of over 10,000 per cent within the past two decades. Kenya and indeed the whole of East Africa have not been left behind in this trade. In Kenya the trade has grown to USD700 million annually (Business Daily, 28 ${ }^{\text {th }}, 2013$ ). In the Kenyan economy, the trade is rivaling the key foreign exchange earners such as tourism, tea, and horticulture. This trade according to International AntiCounterfeiting Coalition ranges from handbags, jewelry and shoes to brake pads, electronic cords, pharmaceuticals, and health care supplies. In Kenya the most counterfeit trade include medicinal drugs, electronics, Compact disk (CDs) and pirated software, alcoholic drinks, mobile phones, insurance stickers, iron sheets, pens, and farm inputs (Business Daily, $28^{\text {th }}, 2013$ ). Counterfeit does not discriminate and touches on all product categories.

International Anti-Counterfeiting Coalition suggest that the fake that most of us recognize as fake account for just $4 \%$ of the counterfeit menace, whereas the remaining $96 \%$ comprises of the dangerous fakes that can hurt us. According to World Trade Organization (WTO) counterfeit is unauthorized representation of a registered trademark carried on goods identical or similar to goods for which the trademark is registered, with a view to deceiving the purchaser into believing that he/she is buying the original goods.

Kenyan market is awash with counterfeit goods, it is estimated that the level of counterfeit drugs in Kenya is unacceptably high, for example Kenya Association of Manufacturer (KAM) estimates that over 50 percent of anti-malaria drugs in the market are fake. This is not good for all the economic players be it the consumers or the genuine producers and the government. Kenyan government loses over Ksh 35 billion annually due to the ever increasing counterfeit trade. According to KAM counterfeit goods deny government revenue, compromise consumer health and safety, harm the credibility of government assurance on quality and safety of products. It is therefore clear that if this phenomenon continues unabated economy is likely to weaken further and the life of Kenyans hung on the balance. This study sought to unearth why this phenomenon still perpetuate, more so among the youth who are assumed to be more informed and form sizeable market of electronics, movies and software.

\section{Statement of the problem}

According to a research commissioned by KAM, in East Africa it is estimated that more than US\$ 500 million per annum is lost due to counterfeit. The same research cited that over 30 per cent of medicines sold in Kenya are fake. Some companies lose over 70 per cent of their market to counterfeit, government loses over $\$$ 80 million to this trade, and Kenyan manufacturers incur an annual net loss of over $\$ 42$ million due to 
counterfeit products. In Kenya according to Daily Nation (July 26, 2013) two in every five popular brand spirits are fake and 15 per cent of all alcohol drinks are counterfeit.

If nothing is done, government will continue to loose potential income, consumer health and safety may continue to deteriorate, companies will continue to lose their income, and Kenya will be at risk of being shun by investors. Given this glaring statistics about counterfeit trade in Kenya and the potential danger that it presents, there is need to further research on why consumers are still buying counterfeit products. This research sought to examine the purchasing behavior of counterfeit by youth in Kenya, focusing on electronics, CDs and Software. The study focused on students at Africa Nazarene University in Kenya

\section{Research questions}

This study focused on the following research questions

1. What proportion of consumers had ever bought counterfeit products?

2. What proportion of buyers had bought counterfeit goods knowingly?

3. What factors had pulled accomplices into buying counterfeit goods?

4. Is there a relationship between post purchase experience of counterfeit and continued purchase of counterfeit goods? Or hypotheses that there is no relationship between post purchase experience of counterfeit and continued purchase of counterfeit goods.

\section{Literature Review}

Counterfeit is not a new phenomenon, it has been with us for years, Hamelin, Nwankwo, and Hadouchi (2013) argues that it can be regarded as one of the oldest crime in history. Counterfeit according to WTO can be defined as unauthorized representation of a registered trademark carried on goods identical or similar to goods for which the trademark is registered, with a view to deceiving the purchaser into believing that he/she is buying the original goods. Bian and Moutinho (2011) looks at counterfeit as those products bearing a trademark that resembles or identical to a registered trademark and which infringe on the rights of the holder of the trade mark. These two definitions, seem to agree with what Marketti and Shelly (2009), seem to consider as counterfeitmanufacturing of lookalike products labeling it as an original and 'passing off' this copy as the original product.

From these definitions it is possible that consumers could be buying counterfeit goods unknowingly that is, believing they are genuine or they could be buying counterfeit goods with the full knowledge that they are counterfeit. Whichever the case, several research agree that trade in counterfeit goods has continued to grow over the years (Tom, Garibaldi, Zeng,and Kempen, 2003; Marcketti and Shelley, 2009). This growth in counterfeit present marketers with great challenges in as far as safeguarding the integrity of their products, protecting intellectual property rights and market positioning (Hamelin, Nwankwo, and Hadouchi 2013). Counterfeiting is always on the move as strong brands try to innovate so are the counterfeiting companies.

Counterfeit and pirated products as noted by a research commissioned by KAM, is a billion-dollar industry which is spread worldwide and more prevalent in low income countries. This has been contradicted by several findings which found out that counterfeit is also rampant in developed countries such as Marcketti and Shelley (2009), who carried a research in United State, Heng, Cheng, Lim, and Tambyah (2001) carried their research in Singapore and Hong Kong, Bian and Moutinho (2011) did their research in United Kingdom. All these researches found out there was counterfeit trade in these countries. Counterfeit continues to grow globally due to various reasons. First, the high margins that the counterfeit manufacturers are able to earn, secondly the opening up of huge economies in the recent past such as in Asia and Eastern Europe (Marcketti and Shelley, 2009). Counterfeiting has been connected to terrorism as noted by Wood (2003) as cited by Marcketti and Shelley (2009) a notion that is supported by a research commissioned by KAM.

Research on counterfeit has been on diverse issues and the findings has also been diverse and at time mixed. This fact can be seen in the table1 which summarize some of the research that has attempted to tackle the phenomenon of counterfeit.

Table 1; Summary of counterfeit research findings

\begin{tabular}{|c|c|}
\hline Researchers & Findings \\
\hline Hamelin, Nwankwo, Hadouchi (2013) & $\begin{array}{l}\text { - } \quad \text { Health, integrity and disappointment risk are the most countervailing factors } \\
\text { - } \\
\text { - } \\
\text { - }\end{array}$ \\
\hline Fan, Lan, Huang, and Chang (2013) & - $\quad$ Price does not influence purchase of counterfeit goods \\
\hline Norum and Cuno (2011) & 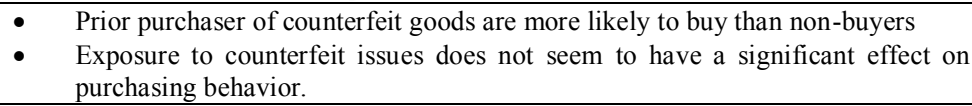 \\
\hline Chaundhry and Stumpf(2011) & $\begin{array}{ll} & \text { Product category matters in counterfeit purchase } \\
\text { - } & \text { Males likely to buy counterfeit goods } \\
\text { - } & \text { Younger people more likely to purchase counterfeit goods }\end{array}$ \\
\hline
\end{tabular}




\begin{tabular}{|c|c|}
\hline Bian and Moutinho (2011) & $\begin{array}{l}\text { - Consumer have more favorable perceptions about genuine branded products } \\
\text { than counterfeit branded products } \\
\text { - Financial risk is not a key deterrent for purchasing counterfeit } \\
\text { - Social risk has negative impact on purchase intention of counterfeit branded } \\
\text { products. }\end{array}$ \\
\hline Marcketti and Shelley (2009) & $\begin{array}{l}\text { - Concern, knowledge, and attitude significantly contributed to consumers' } \\
\text { willingness to pay more for non-counterfeit goods }\end{array}$ \\
\hline Kempen (2003) & $\begin{array}{l}\text { - } \quad \text { Counterfeits have potential to enhance welfare of low-income consumers } \\
\text { - } \quad \text { Low degree of existence of ex post disappointment }\end{array}$ \\
\hline $\begin{array}{l}\text { Tom, Garibaldi, Zeng and Pilcher } \\
\text { (1998) }\end{array}$ & $\begin{array}{l}\text { - } \\
\text { - } \\
\text { - } \\
\text { - }\end{array}$ \\
\hline
\end{tabular}

\section{Forces driving counterfeit trade}

Counterfeit is driven by both demand and supply forces. On the supply side it is driven by institutional factors of where it operates, such as penalties imposed in a market and likelihood of detection. On the demand side, consumer behavior is the main driver. So in order to address the menace the two must be addressed. The supply side can be dealt with by the government since it revolves around institutional factors and their capability to deter or encourage the trade. Staake, Thiesse and Fleisch (2009) asserted that despite the high margins that illegal activities attracts, consistent seizures and raids can drive illicit actors out of business, this point to the need by the government to have a strong enforcement mechanism to fight this trade.

The demand side is interesting for researchers as it entails the people who are buying and consuming the product. Price and quality has been cited as the most driver of counterfeit purchase by researchers (Hamelin, Nwankwo, and Hadouchi (2013) and Tom, Garibaldi, Zeng and Pilcher (1998)). Tan (2002) as cited by Staake, Thiesse and Fleisch (2009) found out that purchase intentions are influenced by the perceived moral intensity, this findings seem to partly agree with the Hamelin, Nwankwo, and Hadouchi (2013), where integrity was found to be one of the countervailing factors to counterfeit purchase.

Trevor and Dhaliwal (2004) found that 48 per cent of their respondents buy pirated software regularly in Singapore and noted that this was relatively low compared to 81 per cent in Hong Kong. Major drivers that they identified for counterfeit purchase included availability of pirated software and high cost of genuine products. These findings agree with those of Hamelin, Nwankwo, and Hadouchi (2013) and Fan, Lan, Huang, and Chang (2013), but Trevor and Dhaliwal (2004) findings were unique in that it looked at availability of counterfeit goods an aspect that most researcher ignores. Most research seem to agree that male are more likely to purchase counterfeit goods unlike their female counterfeit (Chaundhry and Stumpf, 2011; Hamelin, Nwankwo, and Hadouchi ,2013). Price as a driver for purchase of counterfeit products showed mixed findings from different researchers .Tom, Garibaldi, Zeng and Pilcher (1998) found that price influence the purchase of counterfeit among the responded. This was supported by Hamelin, Nwankwo, and Hadouchi (2013). However, Fan, Lan, Huang, and Chang (2013), contradicted these findings when they found that price and purchase of counterfeit goods has no correlation.

Very little attention has been given to after purchase experience of counterfeit goods in influencing repeat purchase of the same. Only Kempen (2003), who included this variable and found that there existed low level of after purchase disappointment. This study will seek to contribute to this area as well, by seeking to understand how the experience of those who have purchased counterfeit products impact on their future or next purchase.

As it can be seen from Table 1 research in this field is spread and more skewed toward developed nation where they have well established mechanism to deal with counterfeit. Very little exist about counterfeit trade in less developed nations where most nations are still struggling with legal framework regarding the trade. This research will be one of its kinds in trying to advance the body of knowledge in as far as counterfeiting is concerned in young but vibrant economies such as Kenya. Attention will be paid to electronic products

\section{Counterfeit trade in Kenya}

As is the case with counterfeit trade around the globe, it keeps on evolving. The traditional counterfeit involved luxury products sold in limited venues, this is no longer the case in today's economy (Marcketti and Shelley, 2009). Counterfeit is being felt across every product range from fake food stuff to auto spares. In Kenya the problem is more compounded, in some instance the consumer can hardly tell the fake from the original due to the fact that the pricing and packaging are almost similar. A study that was commissioned by KAM reports that some companies have lost as high as 70 per cent of their market share in East Africa due to counterfeit products. 
The study by KAM noted that counterfeiting is more prevalent in low economies due to several factors; inadequate legal and enforcement mechanism, low purchasing power of consumer due to poverty level, consumer ignorance, globalization, demand /supply situation of original products, and liberalization of domestic markets. In recent past the counterfeit trade in Kenya has taken a new twist as noted by Daily Nation (July, 26, 2013) almost everything in Kenya now have been counterfeited ranging from medicines, juices, sugar, iron sheet, cigarettes, electronics, fertilizers, shoes and other apparels, vehicle spare parts, insurance stickers, ironsheets, pens, and beauty products.

According to the same research there are different players in counterfeit trade; trademark owner, manufacture of counterfeit products, the distributors, consumers, genuine manufacturer, outsources manufacturers, customs authorities and other government agencies. Each of these players is affected differently by the trade. The impacts of counterfeit to a country cannot be overemphasized, job losses and reduced Gross Domestic Product (GDP) are just but obvious results. The importers of counterfeit products do not pay fair amount of duty, the seller do not pay taxes. This in turn create unlevelled playing field for the industry players, more so those who are manufacturer of genuine products. Since it is difficult to compete with these counterfeit products given they do not incur same cost in bringing their products in the market as the genuine producers would incur, investor lose their investment as the hard work of creative and innovative designers is devalued (KAM commissioned research).

\section{Knowledge Gap}

As is evident from the review of the literature, scanty information exists in Kenya about the demand forces behind the ever-increasing purchase of counterfeit products. Furthermore, the existing literature even from other countries seems to offer mixed and sometimes contradicting findings. For example, Bian and Moutinho (2011) findings that financial risk is not a deterrent to counterfeit purchase was contradicted by Hamelin, Nwankwo, and Hadouchi (2013). Hamelin, Nwankwo, and Hadouchi (2013) conclusion that price is a major driver of purchasing counterfeit goods was contradicted by Fan, Lan, Huang, and Chang (2013), who saw no relation between price and purchase of counterfeit good. Swee et al (2001) as cited by Staake Thiesse and Fleisch (2009) noted that counterfeit consumers regard the purchase of fakes as less risky and less unethical. The purpose of this study was therefore to get a more accurate position on factors that influence purchase of counterfeit products, specifically purchase of ICT products among the youth in the university.

\section{Methodology}

The study adopted cross-sectional survey design. A sample of 142 students selected randomly was served with questionnaires and variables were assessed on a 5-point Likert scale. Descriptive statistics, factor analysis and chi-square test were used to analyze the data.

\section{Data analysis}

All the questionnaires issued were returned on time. This indicates a very good response rate from the survey. In this study, it was found out that 122 out of 142 respondents representing $86.522 \%$ of the respondents had purchased counterfeit products. This is an overwhelming consumption of counterfeit goods given that the study involved more educated and hence exposed consumers who are expected to be more informed. The study also found out that $47.544 \%$ had bought counterfeit products knowingly while $52.436 \%$ were led in one way or the other cheated by sellers into buying counterfeits. This could imply that majority of consumers had problems in distinguishing counterfeit from original products.

The study also showed that of all those who had bought counterfeits IT products, $41 \%$ had bought counterfeit movies DVDs, 23\% music DVDs, 17\% mobile phones while 13\% computers. Other popular counterfeits products bought include memory cards, flash disks, medicine, clothes, shoes, television sets and mountain bikes. On the question of how frequently the respondents made the purchase, the consumers indicated that it was not on their best interest to consume counterfeits. Only $11 \%$ had formed a habit of buying counterfeit. $19 \%$ often bought counterfeits while $46 \%$ rarely bought the counterfeits while $24 \%$ hardly bought counterfeits.

\section{Factor analysis}

To determine factors that contributed to consumption of IT counterfeit product factor analysis was conducted and 16 factors were extracted that were attributed to purchase of counterfeits. They accounted for $66.481 \%$ of total variance explained showing they were significant but also indicate that there are many more factors that require to be unearthed. 
Table 1: KMO and Bartlett's Test

\begin{tabular}{|l|l|r|}
\hline \multicolumn{2}{|c|}{ KMO and Bartlett's Test } \\
\hline Kaiser-Meyer-Olkin Measure of Sampling Adequacy. & .588 \\
\hline \multirow{2}{*}{ Bartlett's Test of Sphericity } & Approx. Chi-Square & 1937.677 \\
\cline { 2 - 3 } & Df & 1128 \\
\cline { 2 - 3 } & Sig. & .000 \\
\hline
\end{tabular}

From the above table, KMO has a value of 0.588 which shows that factor analysis model is satisfactory for this analysis. A Bartlett's test of spherity has a chi square of about 1937 . 7 with sig. value of 0.000 which is less than 0.005 indicating there is correlation between the variables and so supports the appropriateness of factor analysis model for this analysis.

Table 2 Rotated Component Matrix

\begin{tabular}{|c|c|c|c|c|c|c|c|c|c|c|c|c|c|c|c|c|}
\hline \multicolumn{17}{|c|}{ Rotated Component Matrix ${ }^{\mathrm{a}}$} \\
\hline & \multicolumn{16}{|c|}{ Component } \\
\hline & 1 & 2 & 3 & 4 & 5 & 6 & 7 & 8 & 9 & 10 & 11 & 12 & 13 & 14 & 15 & 16 \\
\hline VAR00037 & .716 & & .186 & & .216 & .158 & & & .102 & $.151^{-}$ & & & & & & \\
\hline VAR00036 & .648 & $\begin{array}{r}- \\
.130\end{array}$ & & & .111 & & & $\begin{array}{r}- \\
.125\end{array}$ & .310 & .147 & .214 & .120 & & & .126 & $\begin{array}{r}- \\
\\
\end{array}$ \\
\hline VAR00038 & .614 & .314 & & & & & & & & & & .143 & & & & \\
\hline VAR00040 & .596 & & .411 & & & & & & & .139 & & .202 & & $\begin{array}{r}-189 \\
\end{array}$ & & .183 \\
\hline VAR00030 & .475 & .127 & & .246 & & .296 & & & .171 & .317 & & .144 & & .279 & .311 & .121 \\
\hline VAR00015 & & .696 & & .152 & & & .121 & .217 & & .112 & & & & & & \\
\hline VAR00014 & & .676 & .161 & .180 & & & .102 & .102 & & & & & & .144 & & .228 \\
\hline VAR00008 & $.193^{-}$ & .508 & & & .224 & .405 & & .142 & .202 & & .189 & & .105 & & .167 & $.127^{-}$ \\
\hline VAR00017 & .151 & .488 & & & .363 & .111 & .251 & $\begin{array}{r}- \\
.191\end{array}$ & $\begin{array}{r}- \\
.132 \\
\end{array}$ & .163 & & $\begin{array}{r}- \\
\end{array}$ & & $\begin{array}{r}- \\
.227\end{array}$ & & \\
\hline VAR00012 & & .384 & .238 & .322 & .102 & & & & .360 & .231 & .201 & & .264 & & .118 & \\
\hline VAR00013 & .200 & .323 & .289 & & & .124 & & .168 & .270 & .113 & .164 & & & $\begin{array}{r}- \\
.300\end{array}$ & $\begin{array}{r}- \\
.113\end{array}$ & .288 \\
\hline VAR00042 & & & .831 & & .108 & .124 & .170 & & .103 & & .114 & & & & & \\
\hline VAR00043 & & & .764 & .226 & & .137 & & & & & .140 & & & & .128 & \\
\hline VAR00021 & & .227 & .189 & .700 & & & & & & .157 & & & .157 & & .128 & $\begin{array}{r}- \\
.138 \\
\end{array}$ \\
\hline VAR00016 & .206 & .328 & & .615 & .279 & .141 & $.131^{-}$ & & & & & & & & .181 & \\
\hline VAR00020 & & .112 & & .555 & & .182 & .237 & .333 & .126 & $\begin{array}{r}- \\
.114\end{array}$ & .344 & & & & .178 & \\
\hline VAR00003 & $\begin{array}{r}- \\
.103\end{array}$ & .140 & & .440 & $\begin{array}{r}- \\
.123\end{array}$ & .157 & .283 & .244 & .333 & & & & .173 & & & .177 \\
\hline VAR00041 & .146 & .142 & .386 & .413 & $\begin{array}{r}- \\
.231\end{array}$ & .222 & & & & & & & .104 & & .256 & .211 \\
\hline VAR00024 & .162 & & & .127 & .688 & & & .151 & & .194 & $\begin{array}{r} \\
.115\end{array}$ & & .257 & & & \\
\hline VAR00009 & & .169 & & .138 & .587 & & & .121 & .271 & $\begin{array}{r}- \\
\end{array}$ & .102 & & $\begin{array}{r}- \\
.179 \\
\end{array}$ & .322 & & .123 \\
\hline VAR00007 & & .144 & .205 & & .584 & .117 & & & & & .168 & .112 & .137 & $\begin{array}{r}- \\
.203\end{array}$ & .224 & \\
\hline VAR00032 & & .183 & .203 & & 431 & .199 & & & .316 & .241 & .387 & .139 & .196 & & & \\
\hline VAR00010 & & & .303 & .220 & .425 & & & & $\begin{array}{r}- \\
.285\end{array}$ & .196 & .168 & .168 & .391 & & & \\
\hline VAR00044 & .189 & .151 & .149 & & & .717 & & $\begin{array}{r}- \\
.105\end{array}$ & & & & .153 & & & & \\
\hline VAR00045 & $\begin{array}{r}- \\
.130 \\
\end{array}$ & & & .186 & & .642 & .130 & .233 & $\begin{array}{r} \\
.113\end{array}$ & & & & .170 & & .121 & \\
\hline VAR00046 & .119 & .143 & .289 & & .169 & .597 & $\begin{array}{r}- \\
\end{array}$ & & & .242 & & .123 & $\begin{array}{r}- \\
.253 \\
\end{array}$ & & & .103 \\
\hline VAR00018 & & & & & & & .754 & & & & .178 & .143 & .166 & & & \\
\hline VAR00019 & & .300 & & .111 & $\begin{array}{r}- \\
.101 \\
\end{array}$ & & .641 & & .172 & & .110 & & & .164 & & $\begin{array}{r}- \\
176 \\
\end{array}$ \\
\hline VAR00001 & & & & .144 & .158 & .120 & .555 & $\begin{array}{r}- \\
.151 \\
\end{array}$ & & & $\begin{array}{r}- \\
.316 \\
\end{array}$ & & $\begin{array}{r}- \\
.113 \\
\end{array}$ & $\begin{array}{r}- \\
.316 \\
\end{array}$ & $\begin{array}{r}- \\
.208 \\
\end{array}$ & .123 \\
\hline VAR00002 & & .281 & .278 & & & & .361 & .120 & & & & & - & .143 & & - \\
\hline
\end{tabular}




\begin{tabular}{|c|c|c|c|c|c|c|c|c|c|c|c|c|c|c|c|c|}
\hline & & & & & & & & & & & & & .199 & & & .322 \\
\hline VAR00005 & & .102 & & & & & & .814 & $\begin{array}{r}- \\
.129\end{array}$ & & & & & & & \\
\hline VAR00004 & & .286 & .204 & & .102 & & .115 & .672 & .133 & $\begin{array}{r}- \\
.150\end{array}$ & & & & & & .140 \\
\hline VAR00006 & $\begin{array}{r}- \\
.376\end{array}$ & & & .169 & & & $\begin{array}{r}- \\
.133 \\
\end{array}$ & .421 & .260 & & & .117 & .143 & .230 & & .212 \\
\hline VAR00029 & .135 & $\begin{array}{r}- \\
.105\end{array}$ & & & .135 & & & & .674 & & $\begin{array}{r}- \\
.274\end{array}$ & & & .152 & & \\
\hline VAR00011 & & & & & & .119 & & .164 & .543 & & .161 & & & $\begin{array}{r}- \\
.313\end{array}$ & .510 & \\
\hline VAR00031 & & & .117 & & & & & $\begin{array}{r}- \\
.135\end{array}$ & & .767 & & & & .139 & & \\
\hline VAR00023 & $\begin{array}{r}- \\
.124\end{array}$ & .172 & $\begin{array}{r}- \\
.122 \\
\end{array}$ & .327 & & $\begin{array}{r}- \\
.196\end{array}$ & .154 & & & .541 & & & & $\begin{array}{r}- \\
.208\end{array}$ & .362 & \\
\hline VAR00033 & & .139 & .195 & .156 & .146 & .236 & & $\begin{array}{r}- \\
.170\end{array}$ & .148 & .500 & .224 & $\begin{array}{r}- \\
.156\end{array}$ & .221 & & $\begin{array}{r}- \\
.114\end{array}$ & .156 \\
\hline VAR00022 & .104 & & & & & & & & $\begin{array}{r}- \\
.103\end{array}$ & & .780 & & $\begin{array}{r}- \\
.131\end{array}$ & & & \\
\hline VAR00035 & .117 & & & .331 & & .126 & .135 & & & & .398 & $.112^{-}$ & .217 & & .241 & .259 \\
\hline VAR00048 & & .130 & & & & .196 & & & & & & .792 & & & & \\
\hline VAR00047 & .133 & $\begin{array}{r}- \\
.177\end{array}$ & & & .205 & .119 & .195 & & & & .195 & .681 & & .161 & & .104 \\
\hline VAR00039 & .461 & & .128 & & & $\begin{array}{r} \\
.125 \\
\end{array}$ & .172 & .183 & .151 & .115 & & .494 & .124 & & & \\
\hline VAR00025 & & & & & .125 & & & & & & & & .841 & & & \\
\hline VAR00027 & & & & & & & & & & & & & & .805 & & \\
\hline VAR00028 & .138 & & .159 & & & & $\begin{array}{r}- \\
.101\end{array}$ & & & & & & & & .798 & \\
\hline VAR00034 & & & & & & & & $\begin{array}{r} \\
.142 \\
\end{array}$ & & & & & & & & .825 \\
\hline VAR00026 & .233 & & $\begin{array}{r}- \\
.149 \\
\end{array}$ & & .187 & .140 & .359 & .292 & $\begin{array}{r}- \\
.134 \\
\end{array}$ & & $\begin{array}{r}- \\
.243 \\
\end{array}$ & & .197 & .243 & & .362 \\
\hline
\end{tabular}

The rotated component matrix shows the loadings of 48 variables on 16 extracted factors taking loadings of approximately 0.5 and above. The 16 factors have been described from their associated variables and the amount of variance they contributed shown in table 3

Table 3 Extraction of variables

\begin{tabular}{|c|c|c|c|c|}
\hline & Variable & $\begin{array}{l}\text { Factor } \\
\text { loadings }\end{array}$ & Factor & Weight \\
\hline VAR00037 & Competition among the youth encourages the behavior & .716 & \multirow{5}{*}{$\begin{array}{c}1 . \\
\text { Youthfulness }\end{array}$} & \multirow[t]{5}{*}{$5.664 \%$} \\
\hline VAR00036 & Peer pressure leads to high purchase of counterfeit & .648 & & \\
\hline VAR00038 & $\begin{array}{l}\text { Declining sense of responsibility among youth encourages } \\
\text { purchase of counterfeits }\end{array}$ & .614 & & \\
\hline VAR00040 & $\begin{array}{l}\text { Imitation of western culture encourages purchase of } \\
\text { counterfeit }\end{array}$ & .596 & & \\
\hline VAR00030 & $\begin{array}{l}\text { Counterfeits have potential to enhance welfare of low- } \\
\text { income consumers }\end{array}$ & .475 & & \\
\hline VAR00015 & Dealers of counterfeit make a kill on counterfeits goods & .696 & \multirow{4}{*}{$\begin{array}{c}2 . \\
\text { Weak regulatory } \\
\text { enforcement }\end{array}$} & \multirow[t]{4}{*}{$5.354 \%$} \\
\hline VAR00014 & $\begin{array}{l}\text { Lack of strong laws to protect intellectual property rights } \\
\text { encourages purchase of counterfeit. }\end{array}$ & .676 & & \\
\hline VAR00008 & Government lack effective control systems on counterfeits & .508 & & \\
\hline VAR00017 & $\begin{array}{l}\text { The high margins that the counterfeit manufacturers are } \\
\text { able to earn encourage their purchase }\end{array}$ & 488 & & \\
\hline VAR00042 & $\begin{array}{l}\text { High levels of unemployment encourages trade with } \\
\text { counterfeits }\end{array}$ & .831 & \multirow{2}{*}{$\begin{array}{c}3 . \\
\begin{array}{c}\text { High unemployment } \\
\text { levels }\end{array}\end{array}$} & \multirow[t]{2}{*}{5.024} \\
\hline VAR00043 & $\begin{array}{l}\text { Uncontrolled hawking of goods increases buying of } \\
\text { counterfeits }\end{array}$ & .764 & & \\
\hline VAR00021 & $\begin{array}{l}\text { Low pricing of counterfeit goods encourage their } \\
\text { purchase }\end{array}$ & .700 & \multirow[t]{4}{*}{$\begin{array}{c}4 . \\
\text { Ignorance }\end{array}$} & \multirow[t]{4}{*}{4.804} \\
\hline VAR00016 & $\begin{array}{l}\text { Low income earners are more likely to buy counterfeit } \\
\text { products }\end{array}$ & .615 & & \\
\hline VAR00020 & $\begin{array}{l}\text { Consumers with low education levels are more likely to } \\
\text { buy counterfeits }\end{array}$ & .555 & & \\
\hline VAR00003 & $\begin{array}{l}\text { Buyers are deceived by dealers into buying counterfeit } \\
\text { goods }\end{array}$ & .440 & & \\
\hline
\end{tabular}




\begin{tabular}{|c|c|c|c|c|}
\hline VAR00041 & $\begin{array}{l}\text { Trade with countries that don't value property rights } \\
\text { encourages consumption of counterfeits }\end{array}$ & .413 & & \\
\hline VAR00024 & Youth are more likely to purchase counterfeit goods & .688 & \multirow{5}{*}{$\begin{array}{c}5 . \\
\text { Insensitivity }\end{array}$} & \multirow[t]{5}{*}{4.613} \\
\hline VAR00009 & $\begin{array}{l}\text { Genuine manufacturers have not done enough to stop } \\
\text { selling counterfeits goods }\end{array}$ & .587 & & \\
\hline VAR00007 & Counterfeits are more attractive to the youth & .584 & & \\
\hline VAR00032 & Inability to detect counterfeits leads to their purchase & -.431 & & \\
\hline VAR00010 & Buying of counterfeit has been a normal way of life & .425 & & \\
\hline VAR00044 & $\begin{array}{l}\text { Aggressiveness of youth sales people encourages fellow } \\
\text { youth to purchase counterfeit }\end{array}$ & .717 & \multirow[t]{3}{*}{$\begin{array}{c}6 . \\
\text { Aggressive promotion }\end{array}$} & \multirow[t]{3}{*}{4.360} \\
\hline VAR00045 & $\begin{array}{l}\text { Proportion of counterfeits for a given products is very high } \\
\text { increasing choice of their purchase }\end{array}$ & .642 & & \\
\hline VAR00046 & $\begin{array}{l}\text { Lack of loyalty to Kenyan products leads to more } \\
\text { purchase of counterfeits }\end{array}$ & .597 & & \\
\hline VAR00018 & $\begin{array}{l}\text { Where terrorism activities are high counterfeit purchases } \\
\text { is enhanced }\end{array}$ & .754 & \multirow[t]{3}{*}{$\begin{array}{l}7 . \\
\text { External influence }\end{array}$} & \multirow[t]{3}{*}{4.320} \\
\hline VAR00019 & Lack of integrity encourages purchase of counterfeit goods & .641 & & \\
\hline VAR00001 & $\begin{array}{l}\text { Influx of tourist encourage purchase of counterfeits in } \\
\text { Kenya }\end{array}$ & .555 & & \\
\hline & & & \multirow{4}{*}{$\begin{array}{l}\text { 8. } \\
\text { Irresponsible } \\
\text { consumption }\end{array}$} & \multirow{4}{*}{4.267} \\
\hline VAR00005 & $\begin{array}{l}\text { Most Kenyan are ignorant of the negative effect of } \\
\text { counterfeits on economy }\end{array}$ & .672 & & \\
\hline VAR00004 & Counterfeits are highly available in Kenyan market & .421 & & \\
\hline VAR00006 & $\begin{array}{l}\text { Consumers are unaware of the effect of counterfeits on } \\
\text { their wellbeing }\end{array}$ & .814 & & \\
\hline VAR00029 & $\begin{array}{l}\text { Negative attitude towards counterfeit significantly } \\
\text { contributed to consumers' willingness to pay more for } \\
\text { non-counterfeit goods }\end{array}$ & .814 & \multirow[t]{2}{*}{$\begin{array}{c}9 . \\
\text { Attitude }\end{array}$} & \multirow[t]{2}{*}{3.842} \\
\hline VAR00011 & $\begin{array}{l}\text { Consumers are unaware of infringement of their rights to } \\
\text { original goods }\end{array}$ & .672 & & \\
\hline VAR00031 & $\begin{array}{l}\text { Low degree of disappointment with earlier counterfeit } \\
\text { encourages repeat purchase }\end{array}$ & .767 & \multirow[t]{3}{*}{$\begin{array}{c}10 . \\
\text { Temporal satisfaction }\end{array}$} & \multirow[t]{3}{*}{3.685} \\
\hline VAR00023 & $\begin{array}{l}\text { Prior buyers of counterfeit goods are more likely to buy } \\
\text { than non-buyers }\end{array}$ & .541 & & \\
\hline VAR00033 & High cost of genuine products encourages counterfeits & .500 & & \\
\hline VAR00022 & $\begin{array}{l}\text { Consumers are not quality sensitive hence go for } \\
\text { counterfeit goods }\end{array}$ & .780 & $\begin{array}{l}\text { 11. Quality } \\
\text { insensitivity }\end{array}$ & 3.643 \\
\hline VAR00048 & $\begin{array}{l}\text { Lack of role models in purchase behavior encourages } \\
\text { purchase of counterfeit }\end{array}$ & .792 & \multirow[t]{3}{*}{ 12. Moral erosion } & \multirow[t]{3}{*}{3.622} \\
\hline VAR00047 & $\begin{array}{l}\text { Rebellion against parental authority contributes to high } \\
\text { purchase of counterfeits }\end{array}$ & .681 & & \\
\hline VAR00039 & Erosion of moral values leads to purchase of counterfeits & .494 & & \\
\hline VAR00025 & Product category matters in counterfeit purchase & .841 & 13. Weak branding & 3.376 \\
\hline VAR00027 & $\begin{array}{l}\text { Loss of money is not a key deterrent for purchasing of } \\
\text { counterfeit goods }\end{array}$ & 805 & 14. Myopia & 3.346 \\
\hline VAR00028 & $\begin{array}{l}\text { It is not seen as an embarrassment to purchase counterfeit } \\
\text { products }\end{array}$ & 798 & 15. Societal approval & 3.344 \\
\hline VAR00034 & $\begin{array}{l}\text { Pricing of counterfeit same as genuine leads to their } \\
\text { increased purchase }\end{array}$ & 825 & $\begin{array}{l}\text { 16. Indiscriminative } \\
\text { pricing }\end{array}$ & 3.218 \\
\hline
\end{tabular}

A chi square test was used to test the hypothesis that there is no relationship between post purchase experience of counterfeit and continued purchase of counterfeit goods. those who had a 'YES' response to buying counterfeit goods were required to respond to the frequency of buying after the first experience on four categories; 1.Quite often, 2.Often, 3. Rarely 4, and Very rarely and the results of the chi-test are presented in the tables 4 :

Table 4 Chi-square test

\begin{tabular}{|l|r|r|r|}
\hline \multicolumn{4}{|c|}{ VAR00001 } \\
\hline & Observed N & Expected N & \multicolumn{1}{|c|}{ Residual } \\
\hline 1.00 & 14 & 30.5 & -16.5 \\
\hline 2.00 & 28 & 30.5 & -2.5 \\
\hline 3.00 & 46 & 30.5 & 15.5 \\
\hline 4.00 & 34 & 30.5 & 3.5 \\
\hline Total & 122 & & \\
\hline
\end{tabular}




\begin{tabular}{|c|c|}
\hline \multicolumn{2}{|c|}{ Test Statistics } \\
\hline & VAR00001 \\
\hline Chi-Square & $17.410^{2}$ \\
\hline $\mathrm{df}$ & 3 \\
\hline Asymp. Sig. & .001 \\
\hline
\end{tabular}

A total of 122 respondents who had earlier purchased counterfeit goods were distributed in the four after purchase categories where each category had at least 5 frequencies. The chi square value of 17.4 tests had sig value 0.001 which is less than 0.005 and is significant at 3 degrees of freedom.

\section{Discussions, conclusion and recommendations}

The study identified 16 major factors that have contributed to consumption of counterfeit products accounting about $66 \%$ of total variance explained. Perception of youthfulness among the respondent was seen as the greatest factor contributing to this trend accounting for $5.664 \%$ of total variance explained. Peer pressure, competition, imitation of other cultures especially western culture were identified as youthful factors contributing to the trend. Majority of the youth seem to have lost sense of responsibility leading to easy consumption of counterfeit. Earlier scholars had not identified youthfulness as major factor and this indicates the dynamic changes involving responses to purchase of counterfeit goods and especially on IT related products.

Weak regulations were identified as the second important factor contributing to this trend. The bodies charged with the responsibility of fighting the menace were either toothless or they are compromised and so creating a room for traders to thrive in this business. This factor accounted for $5.354 \%$ of total variance explained. Enforcing of regulations in developing countries remains a big challenge for the governments and their agencies. Most counterfeit products are not as expensive as genuine products and this could be making them more appealing to low income earners. This is supported by this study, which shows that poverty was identified as a major contributor to consumption of counterfeit products, which accounted for $5.024 \%$ of total variance. Though this supports the finding of Kempen (2003) and Tom, Garibaldi, Zeng and Pilcher (1998), more studies ought to be done because on contrary the focused population in this study was from middle class.

High levels of ignorance and insensitivity, which are closely related, were also found to be major factors accounting for $4.804 \%$ and $4.613 \%$ of total variance explained. This contradicts the findings of Hamelin, Nwankwo, Hadouchi (2013) which had alluded to the fact that less educated women and poor people purchased counterfeit products. This study however, involved university students and therefore it was expected that this would not be a major factor. On contrary, it turned out to be an important issue that requires further investigation. Aggressive promotion by traders of counterfeit, external influence and irresponsible consumption behaviour accounted for $4.360 \%, 4.320 \%$ and $4.267 \%$ respectively. Ability to imitate brand names, logos and colors of particular brands easily contributed significantly. Influx of tourists who were either using counterfeit products or who had the set standard as to what was popular then led to increase in this menace. Desire for temporal satisfaction popular with what is known as "instant generation" accounted for $3.685 \%$ of total variance explained. This is a key driver where the young people want instant solutions and may not have to wait to raise enough money for a genuine product. Coupled with this is morals erosion that accounted for $3.622 \%$ of total variance.

There is general agreement that moral values are declining globally and the purchase of counterfeit products is a clear indicator. Other factors identified include weak branding by genuine products leading to traders in counterfeit exploiting the opportunity created. Consumers cannot easily distinguish between genuine and fake products. Short sightedness, indiscriminative pricing and societal approval of use of counterfeit remains major factors that required some address. From the chi square test we reject the null hypothesis and conclude that there is a relationship between post purchase experience of counterfeit and continued purchase of counterfeit goods. The identified relationship between post buying and continued purchase of counterfeit goods shows that those who had purchased earlier have a lower tendency of making purchase thereafter. Further research should be conducted to identify the possible deterrent so to reduce or eliminate this menace.

\section{Conclusion and recommendation}

Counterfeit trade proves to be a global phenomenon but most prevalent in developing countries. As noted earlier, it is one of the greatest avenues through which government and companies' loose revenue and requires immediate action to save the firms and consumers. This study has established that perception of youthfulness, weak regulations, weak branding, external influence, irresponsibility and moral decline as some of the major factors driving counterfeit trade. Ignorance and poverty were also identified as factors contributing to this phenomenon, however this raised questions as the study was carried out among students largely from middle income families who are also university students. There is therefore need for further study to establish 
relations between ignorance and purchase of counterfeits. This study recommends deliberate education against counterfeit purchase in that a level of learning experience gained from earlier purchase has some positive deterrent response to post purchases.

\section{References}

[1]. Ang, S., Cheng, P., Lim. E. and Tambyah, S. (2001) "Spot the difference: consumer response towards counterfeits" Journal of Consumer Marketing, Vol. 18 No. 3 pp. 219-235.

[2]. Bian, X. and Moutinho, L. (2011). "Counterfeits and branded products: effects of counterfeit ownership" Journal of Products \& Brand Management, Vol. 20. No. 5 pp. 379-393.

[3]. Fan, W., Lan, C., Huang, Y. and Chang, R. (2013) "A study on purchasing behaviour of teenagers in Taiwan: example of counterfeit goods" Journal of Applied Social Psychology, Vol. 43, pp. 1289-1300.

[4]. Hamelin, N., Nwankwo, S. and Hadouchi, R. (2013) "Faking brands: consumer responses to counterfeiting" Journal of Consumer Behaviour, Vol. 15 pp. 159-170.

[5]. Kempen, L.V. (2003) "Fooling the eyes of the beholder: deceptives status signalling among the poor in developing countries" Journal of International Development, Vol 15, pp. 157-177.

[6]. Kenya Association of Manufacturers (KAM) Counterfeits menace accessible in Marcketti, S. and Shelley, M. (2009) "Consumer concern, knowledge and attitude towards counterfeit apparel products” International Journal of Consumer Studies, pp.327-337.

[7]. Norum, P. and Cuno, A. (2011) "Analysis of the demand for counterfeit goods" Journal of Fashion Marketing and Management, Vol.15 No.1 pp. 27-40.

[8]. Staake, T., Thiesse, F. and Fleisch, E. (2009) "The emergency of counterfeit trade: a literature review" European Journal of Marketing, Vol. 43 No.3/4

[9]. Stumpf, S. and Chaudhry, P. (2011) "Consumer complicity with counterfeit products" Journal of Consumer Marketing, 28/2 pp. $139-151$.

[10]. Tom, G., Garibaldi, B., Zend, Y. and Pilcher, J. (1998) “Consumer Demand for counterfeit goods” Psychology \& Marketing, Vol. 15. No.5, pp. 405-421.

[11]. Trevor, T. and Dhaliwa, J. (2004) "A reversed context analysis of software piracy issues in Singapore" Information \& Management, Vol. 41 No. 8, pp.1037-1042. 